\title{
Explaining the safety of children's parks based on the physical components of the space (Case study: Parks in Region 1 of Mashhad)
}

\author{
Hoda Behravesh' \\ Katayoon Alizadeh" \\ Hamid Jafari"l'
}

\begin{abstract}
Attention to the safety of children and adolescents as an effective stratum of society is inevitable. The stratum which the future of every city and country is in their hands. Nowadays, children in addition to nutrition, clean air and a shelter, need a safe and healthy open space to play and communicate with the environment. Flaws of urban spaces do not allow children to experiment and bring them to digital devices and solitaire games. The result is nothing but the growing individualist kids with a spirit of isolationism, a topic that can be called a threat to the health of the community. The present study is a small step towards recognizing the issues of the sense of security of children in the parks of Mashhad. In this research, the physical characteristics and space design, which include pass way quality indicators, lighting, urban furniture, and ultimately the security of space in parks of region 1 of Mashhad municipality will be analyzed. In this study, the research method is descriptiveanalytical and with the understanding of effective physical indices on security through field, documentary and library studies, and comparing the contribution of these indices to other physical indices in similar samples, we explain the importance of these indices. Based on the data the most important physical factors affecting the improvement of security of children's urban parks are the attention to the lighting index of all parks at nights, and also the reduction of out-of-sight locations and inducing fear in the design of the parks.
\end{abstract}

Keywords: Security; Urban Parks; Child; Physical Indices; Mashhad

I Ph.D. Student of Geography and Urban Planning, Mashhad Branch, Islamic Azad University, Mashhad, Iran Hoda.Behravesh@mshdiau.ac.ir

II Assistant Professor, Department of Geography, Mashhad Branch, Islamic Azad University, Mashhad, Iran katayoon_alizadeh@yahoo.com

IIIAssistant Professor, Department of Geography, Mashhad Branch, Islamic Azad university, Mashhad, Iran hamidjafari@yahoo.com 


\section{Introduction}

On the eve of the third millennium, urban public spaces have been regarded as a third place that plays a key role in the establishment of social interaction. Public spaces, urban spaces and artificial environments that citizens should be able to access without restriction (Rafieian, 2010). Children who living in inappropriate neighborhoods show stressful disorders, such as difficulty in controlling communication with others and fear and anxiety. Insecurity, bustle, noise pollution, ruinous and insecure places, and places with a lack of green space related with degrees of negative outcomes of psychological stress. For children, living near noise pollution is more tolerable than lack of green play space and dynamic skills. When population density is high, the occurrence of low collaboration and aggression behaves increase (Dannenberg ,2011).

Playing in the streets with high traffic and near residential apartments in leisure time of families is a problem that endangers children's play. The only children's safe haven is the parks that are often used by children on special days because of being away from their place of residence. The development of game parks in each region and region returns group games to children. The lack of access of many children to toys in terms of family poverty or parents' lack of understanding of their necessity impairs the children's development and growing, and in fact deprives children of activities and movements that are fun and enjoyable. Today, the formation of play houses with all kinds of toys alongside parks, in the heart of kindergartens and educational institutions, provides a bright future free of any concerns. As in some countries, such places allow for hours of deprived children and lack of gaming equipment to play with leisure and without worry, to play peacefully with moments of play and to direct the inherent instinct and desire (Norouzi, 2014). In this article, the main goal is evaluation of physical design indicators affecting the feeling of children's safety which In this regard, a collection of indicators extracted from various sources and the preparation of a survey form for the required information has been gathered. In line with the research goals, the following questions have been raised:

- What are the effective factors in improving the safety of urban parks? 
- Which of the urban physical indicators is more effective in children's sense of safety?

- What is the status of an effective index in improving the security of parks in the region of Mashhad?

\subsection{Background research}

- An article titled "Analysis of Understanding Security in Urban Parks" which pays attention to the perceived safety of urban parks (Rengin Zengel, 2017). This study contributes to existing literatures with an on-site research on perceived safety in urban parks of İzmir, Turkey. In the study, environmental, demographic and perceptual factors have been utilized to explain perceived safety in urban parks. Research results shows that the profound importance of "fear of crime" on perceived safety in urban parks are in line with findings of previous research (Wekerle and Whitzman,1994; King et al., 2000; Zakarian et al., 1994). However, this study has enhanced the meaning of perceived safety by indicating the significance of finding anxiety and environmental satisfaction for sense of safety in urban parks. The results also supported statistically the statement of Lawton and Kallai's study (2002) that stresses the relation between finding and safety perception with a cross cultural study.

- A research on children and adolescents safety and security (preventing violence in and around schools) that is a planning guide to creating safe, calm and non-violent learning spaces (Ministry of Foreign Trade and Development,2015). That is statutory guidance from the Department for Education issued under Section 175 of the Education Act 2002, the Education (Independent School Standards) Regulations 2014, and the Non-Maintained Special Schools (England) Regulations 2015. Schools and colleges in England must have regard to it when carrying out their duties to safeguard and promote the welfare of children. For the purposes of this guidance children includes everyone under the age of 18 .

-A linear regression model, analyzed the effects of fear of crime on walking in Australia. The results of their findings showed that with increasing the number of interventions and some decisions, can reduce the fear of crime and increase the amount of walking (Foster,2014). This study provides longitudinal evidence that changes in residents' 
fear of crime influence their walking behaviors. Interventions that reduce fear of crime are likely to increase walking and produce public health gains.

-Analyzed the development of crime prevention through environmental design in both the United States and the United Kingdom separately. They provide the experience of the two countries to other countries that are willing to step in this direction (Schneider \& Kitchen, 2013)

- In a research entitled "Investigating the role of urban landscape components in promoting the level of sense of security in urban public spaces" shows that despite the security, the sense of security in the studied area from the perspective of the inhabitants is lower than the average level (Moayedi, 2013)

\section{Theoretical foundations}

\subsection{Children's public spaces and urban parks:}

The need for children to play globally is recognized as a fundamental right in childhood (Brussoni, 2012). Public spaces for play include parks, plaques, green areas, playgrounds and sidewalks. Safety issues include natural disasters and human disasters (fires, bullying, crime, violence, accidents, etc.) (Senda, 2015). Urban spaces are spaces that will be sustained by the presence and movement of citizens, a presence that is intertwined with their activity and displays the dynamics of life (Mortazavi, 2011). The environment has a direct impact on every living thing, affects behavioral choices and uses the senses. Therefore, it should pay special attention to the needs of all users (Qarebiglu, 2012). Urban spaces have a unique role in meeting the social and individual needs of children and adolescents. These spaces allocate a major part of time and daily living environment of residents, including children and adolescents, and from a humanities engineering perspective, they impact on enhancing the quality of these spaces can contribute to the health and growth of physical strength, enhancing social interactions and group solidarity, and nurturing children's and adolescent creativity. Urban spaces should seek to develop children's participation in 
shaping their surroundings, a practical partnership that creates a child's interest and belonging to the city (Kiani and Ismailzadeh, 2012).

\subsection{Features of child-friendly urban space:}

Amusement spaces in urban parks are important for the mental, physical and psychological growth and well-being of children. Not only the lack of safe and secure amusement spaces cause mental and physical harm to children, it also results in the loss of opportunities for children to play outdoors (Dong, 2017). Comfort and safety and security, link to nature, link to history, culture and identity, charm and novelty, readability and access to facilities, child-friendly institutions and spaces and attention to children with disabilities are key factors in designing a child's space (Azmoude, 2012). Preventing crime through environmental design also assumes that correct environmental planning can reduce crime rates in addition to improving quality of life (Park, 2010).

Security \& Safety:

The safety component refers to environmental factors that are unavoidable in the event of failure to provide the proper conditions, it is inevitable and potentially threatening the lives and property of attendees, pedestrians and observers (Kelly, 2009). The security component also refers to crimes against individuals and their property, which in failure to provide preventive conditions will potentially threaten passers-by and observers' property and lives. A safe urban space in the full sense includes both of the above-mentioned components, and the conditions arising from the joint chapter of the two can be described as a safe urban space.

\subsection{Physical components affecting children's safety in urban parks:}

Lighting:

Light pollution means the lack of proper lighting in urban and public spaces. A good lighting system increases the potential risks that violators may be identified and increases the chance that someone will assist a victim (Akbari and Pak Bonyan, 2012). Lighting to 
enhance safety understanding, while it may not reduce real mass of crime, but improved lighting provides more night watch (www.nrpa.org)

Space Visible:

In a way that each space is within the domain of the control of specific controllers. Space controllers may be the group or individual who is responsible for that space. Playgrounds that have tutorials and guides that can provide children with new and exotic games and provide support, despite the dangers, by sharing and learning ways to play in nature, attract parental interest and have a high utilization rate. (Senda, 2015)

\section{Access:}

Natural access controls include clearly defined boundaries for the use of asphalt pavements, lighting and landscaping to accurately direct people to entrances and exits, the use of fences, walls or landscaping to prevent public access to dark, unregulated areas that it also acts as a psychological deterrent (Clifton L, 2013).

\section{Vegetation:}

Green space is more associated with increased social security in the living environment, except in completely urban areas where enclosed green space is associated with decreased social security. Green space in most urban areas is a matter of social security concern (Maas, 2009).

\subsection{Urban furniture:}

In parks, train stations, buses and other public places, the use of chairs and benches is limited for a period of time and should be avoided people from lying down or sitting in an unusual position. This type of design strategy is sometimes referred to as "hostile architecture 1" or "unpleasant design 2" (Savicic, 2016).

\subsection{Space flexibility:}

Urban flexibility refers to the ability of the city system and all related social, environmental and technology networks to respond to needs in a critical and specific 
environment at the same time, and to be able to update and coordinate fast in different situations (Meerow, 2016).

Figure 1 - Mina Park
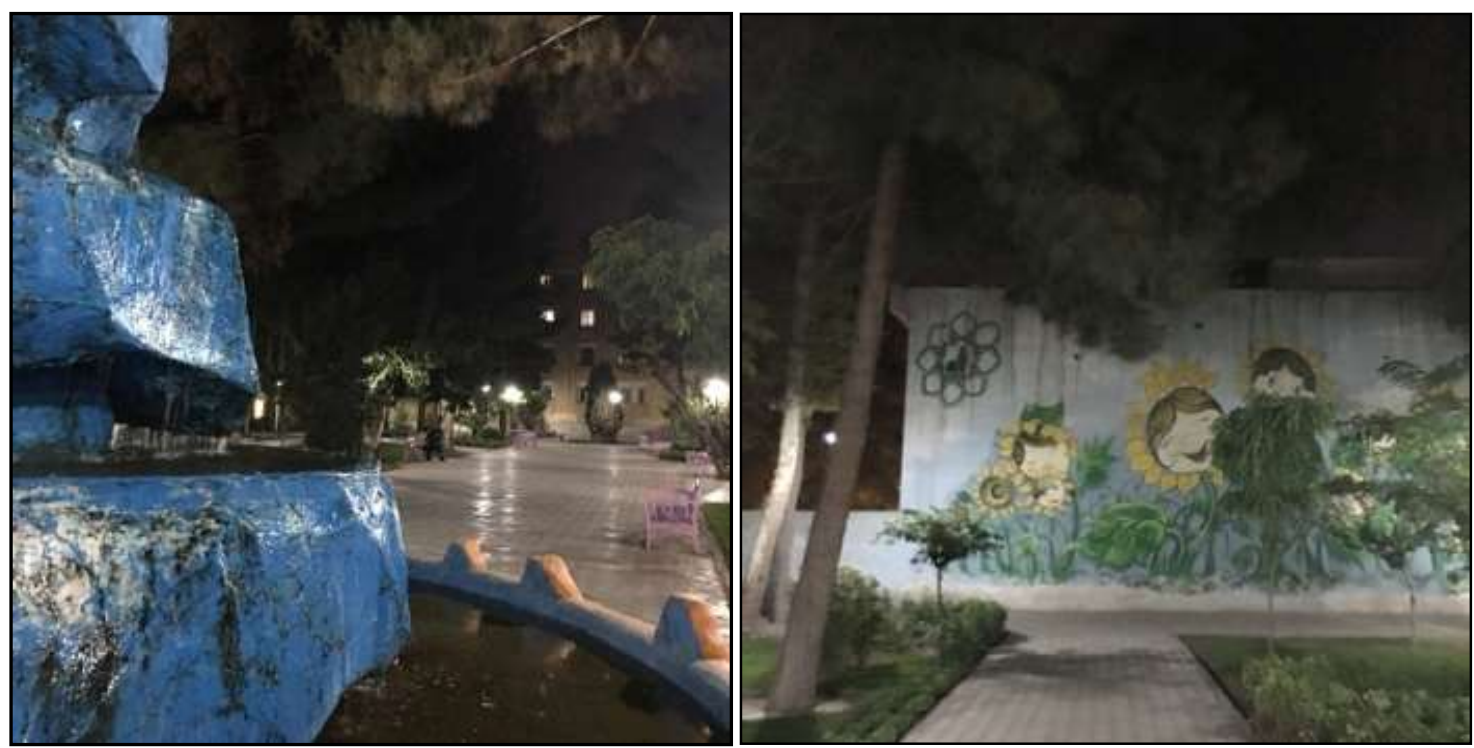

Mina Park (Night Lighting)

\section{Materials and Methods}

The purpose of this research is applied type and it has been done by descriptiveanalytic method. Documentary and field methods (questionnaire) were used to collect the research data, also based on effective indicators and criteria in the research subject and by Likert spectrum method questionnaire items were designed and according to the statistical population of Region 1 of Mashhad municipality that is equivalent to 4 inhabitants based on population and housing census 2016 and with the help of Cochran formula, volume of the sample was determined and in total 180 questionnaires (150 questionnaires from people and 30 questionnaires from expert) were completed randomly. In this regard, according to the research topic, which explains the safety of children's parks based on physical components of space in parks of Region 1 of Mashhad, Friedman average comparison test and ranking were used to derive inferential analyzes from questionnaires. 
Table 1 - Number and percentage of respondents in terms of age

\begin{tabular}{c|c|c|c}
\hline Group & Age & Amount & Percentage \\
\hline \multirow{4}{*}{ Managers } & 20 to 30 years & 9 & 30.0 \\
\cline { 2 - 4 } & 30 to 40 years & 4 & 13.3 \\
\cline { 2 - 4 } & 40 to 50 years & 6 & 20.0 \\
\cline { 2 - 4 } & 50 to 60 years & 5 & 16.7 \\
\cline { 2 - 4 } & More than 60 years & 6 & 20.0 \\
\cline { 2 - 4 } & Total & 30 & 100.0 \\
\hline \multirow{4}{*}{ Citizens } & Less than 18 years & 28 & 18.7 \\
\cline { 2 - 4 } & 18 to 35 years & 74 & 49.3 \\
\cline { 2 - 4 } & 35 to 64 years & 31 & 20.7 \\
\cline { 2 - 4 } & More than 64 years & 17 & 11.3 \\
\cline { 2 - 4 } & Total & 150 & 100.0 \\
\hline
\end{tabular}

According to the above table, most of the managers (30.0\%) are between 20 and 30 years old and most of the population is in the age group of 18 to 35 .

Mashhad, the capital of Khorasan Razavi province, is located in northeast of Iran, 966 kilometers from Tehran. Its height is 985 meters above sea level, its area is about $351.4 \mathrm{~km} 2$ and its population is about 3,057,679 people in 2017 (Mashhad Municipality Census, 2017) which according to 2018 statistics, the total area of green space in Mashhad is 52,754,622.

According to the latest surveys of Mashhad parks and green spaces in 2018, the number of parks in Mashhad region 1 is 39. And the population of the area is 167,013 people in Mashhad.

\subsection{Analysis of safety of children's parks based on the physical components of the} space:

This research has three questions:

- What are the effective factors in improving the safety of urban parks?

- Which of the urban physical indicators is more effective in children's sense of safety?

- What is the status of an effective index of improving the security of parks in the region of Mashhad? 
For investigating the first and third questions, manager's questionnaire was used and for investigating the second question, the citizens' questionnaire was used. Due to the fact that the factors and indicators are in the Likert spectrum, they are therefore not normal and nonparametric tests should be used.

\subsection{Studying the first question}

First question: What are the effective factors in improving the safety of urban parks?

Effective physical factors are determined using the nonparametric test of the mark. Given that the responses are in the 5th Likert spectrum, the average of the responses is 3, so the responses are compared with the number 3 . The results are in Table 7.

Table 2 - Signal test results to examine the effective physical factors in improving the safety of urban parks

\begin{tabular}{|c|c|c|c|c|c|}
\hline Factors & $\begin{array}{c}\text { Number } \\
\text { of } \\
\text { observatio } \\
\text { ns more } \\
\text { than } 3\end{array}$ & $\begin{array}{l}\text { Numb } \\
\text { er of } \\
\text { observati } \\
\text { ons less } \\
\text { than } 3\end{array}$ & $\begin{array}{l}\text { Numbe } \\
\text { r of } \\
\text { observati } \\
\text { ons equal } \\
\text { to } 3\end{array}$ & $\begin{array}{l}\text { Tes } \\
t \\
\text { statist } \\
\text { ic }\end{array}$ & $\begin{array}{l}\text { Signifi } \\
\text { cance } \\
\text { level }\end{array}$ \\
\hline $\begin{array}{l}\text { Attention to the } \\
\text { safety index of } \\
\text { playgrounds for } \\
\text { children and teens in } \\
\text { parks }\end{array}$ & 30 & 0 & 0 & $\begin{array}{c}- \\
5.295\end{array}$ & 0.000 \\
\hline $\begin{array}{l}\text { Attention to the } \\
\text { safety index of floor } \\
\text { coverings, passages } \\
\text { and bridges for } \\
\text { children, the elderly, } \\
\text { the disabled, etc. }\end{array}$ & 30 & 0 & 0 & $\begin{array}{c}- \\
5.295\end{array}$ & 0.000 \\
\hline $\begin{array}{l}\text { Attention to the } \\
\text { safety index of } \\
\text { benches, electric } \\
\text { lighting gates, drinking } \\
\text { water and... for all users } \\
\text { of the park }\end{array}$ & 30 & 0 & 0 & $\begin{array}{c}- \\
5.295\end{array}$ & 0.000 \\
\hline
\end{tabular}




\begin{tabular}{l|l|l|l|r|r}
\hline $\begin{array}{l}\text { Reducing out-of- } \\
\text { visibility locations and } \\
\text { provoking sense of } \\
\text { fear in park design }\end{array}$ & 30 & 0 & 0 & - & 0.000 \\
\hline $\begin{array}{l}\text { Attention to the } \\
\text { lighting index of all } \\
\text { parts of the park at } \\
\text { night }\end{array}$ & 30 & 0 & 0 & - & 0.000 \\
\hline
\end{tabular}

According to the above table, the significance level for all factors is 0.000 and less than 0.05 , and the number of observations is more than the number 3 , more than the other groups, so $95 \%$ confidence can be said:

The effective factors in improving the safety of urban parks are:

- Attention to the safety index of playgrounds for children and teens in parks

- Attention to the floor covering safety index, passageways and bridges for children, the elderly, the disabled, etc.

- Attention to the safety index of benchmarks, electric lighting gates, drinking water and ... for all users of the park

- Reducing out-of-visibility locations and provoking a sense of fear in park design

- Attention to the lighting index of all parts of the park at night

\subsection{The ranking of effective physical factors in improving the safety of urban parks using Friedman test}

In this section, using Friedman's test, the physical factors affecting the improvement of urban park security are ranked and the most important physical factors are identified.

Table 3 - Ranking of effective physical factors in improving the safety of urban parks

\begin{tabular}{l|c}
\hline \multicolumn{1}{c|}{ Factors } & Average rating \\
\hline $\begin{array}{l}\text { Attention to the lighting index of all parts of the park } \\
\text { at night }\end{array}$ & 3.75 \\
\hline $\begin{array}{l}\text { Reducing out-of-visibility locations and provoking a } \\
\text { sense of fear in park design }\end{array}$ & 3.67 \\
\hline
\end{tabular}




\begin{tabular}{l|c}
\hline $\begin{array}{l}\text { Attention to the safety index of playgrounds for } \\
\text { children and teens in parks }\end{array}$ & 3.58 \\
\hline $\begin{array}{l}\text { Attention to the floor covering safety index, } \\
\text { passageways and bridges for children, the elderly, the } \\
\text { disabled, etc. }\end{array}$ & 2.00 \\
\hline $\begin{array}{l}\text { Pay attention to the safety index of benches, light beam } \\
\text { gates, drinking water and ... for all users of the park }\end{array}$ & 2.00 \\
\hline Test statistic & 76.508 \\
\hline significance level & 0.000 \\
\hline
\end{tabular}

According to the above table, the most important physical factor affecting the improvement of urban park security is the "attention to the lighting index of all parts of the park at night".

\subsection{Studying the second question}

Second question: Which of the metropolitan indices has more impact on children's sense of safety?

In the second question, the research identifies the factors that have the greatest impact on the child's sense of safety in his or her parents' eyes. For this purpose, Friedman's non-parametric test is used.

Table 4 - Ranking of urban physical indicators that affect children's sense of security (parental)

\begin{tabular}{l|c}
\hline \multicolumn{1}{c|}{ Indicators } & Average rating \\
\hline $\begin{array}{l}\text { Are there any places in the park that go out of sight and } \\
\text { induce fear? }\end{array}$ & 4.90 \\
\hline $\begin{array}{l}\text { Are there areas of quiet and cozy corners in the park } \\
\text { where there is a possibility of doing wrong and }\end{array}$ & 4.85 \\
misconduct? & 4.06 \\
\hline $\begin{array}{l}\text { Is there a rest in mind about the absence of offenders } \\
\text { and addicts when you are having fun in the park? }\end{array}$ & \\
\hline
\end{tabular}




\begin{tabular}{l|c}
\hline $\begin{array}{l}\text { Are you happy with the lighting of the park at night and } \\
\text { feel secure? }\end{array}$ & 4.02 \\
\hline $\begin{array}{l}\text { To what extent do you know the playground for children } \\
\text { and teens to play safe and secure? }\end{array}$ & 3.45 \\
\hline $\begin{array}{l}\text { Do you evaluate the coverage of the floor, passages and } \\
\text { stairs of the park for children, the elderly, the disabled, } \\
\text { etc.? }\end{array}$ & 3.38 \\
\hline $\begin{array}{l}\text { Do you think that benches, electric light beacons, } \\
\text { drinkers and ... are safe for all groups of users? }\end{array}$ & 3.33 \\
\hline Test statistic & 117.094 \\
\hline significance level & 0.000 \\
\hline
\end{tabular}

According to the above table, the significance level for the ranking of urban physical indicators affecting children's sense of safety (from the viewpoint of parents) is 0.000 and less than 0.05 , so with $95 \%$ confidence, the effect of the physical indices in the feeling of child safety is different. Indicators of urban physical effective on children's sense of safety (from the viewpoint of parents) in order of great effect, are as follows:

- Are there any places in the park that go out of sight and induce fear?

- Are there areas of quiet and cozy corners in the park where there is a possibility of doing wrong and misconduct?

- Is there a rest in mind about the absence of offenders and addicts when you are having fun in the park?

- Are you satisfied with the lighting of the park at night and feel secure?

- To what extent do you know the playground for children and teens to play safe and secure?

- Do you evaluate the coverage of the floor, passages and stairs of the park for children, the elderly, the disabled, etc.?

- Do you think that benches, electric light beacons, drinkers and ... are safe for all groups of users? 
Table 5 - Ranking of urban physical indicators that affect children's sense of safety (from the viewpoint of children)

\begin{tabular}{l|c}
\hline \multicolumn{1}{c|}{ Indicators } & Average rating \\
\hline Are you treated well in the park? & 8.90 \\
\hline Is there enough light in the streets and in the park at night? & 8.46 \\
\hline $\begin{array}{l}\text { Are respected all children with any dress and nationality and } \\
\text { race in your neighborhood? }\end{array}$ & 8.02 \\
\hline Are shops close to the park suitable? & 7.02 \\
\hline Are there different ways to get to the park from the home? & 6.06 \\
\hline Do you feel safe from commuting cars around the park? & 5.94 \\
\hline $\begin{array}{l}\text { If you are at risk out of home and in the park, is there anyone } \\
\text { to help you? }\end{array}$ & 5.94 \\
\hline Do you feel secure when you are alone in the park? & 5.62 \\
\hline $\begin{array}{l}\text { Are there in the neighborhood adult's violence and serious } \\
\text { fights? Do you feel safe about this? }\end{array}$ & 5.62 \\
\hline Do you feel safe against a fight with other children? & 5.58 \\
\hline Do you feel safe to walk to the park? & 5.50 \\
\hline $\begin{array}{l}\text { Are there people other than family in your neighborhood who } \\
\text { you trust them in times of danger? }\end{array}$ & 5.30 \\
\hline Test statistic & 375.325 \\
\hline significance level & 0.000 \\
\hline
\end{tabular}

According to the above table, the significance level for ranking of urban physical indicators affecting children's sense of safety (from the viewpoint of children) is 0.000 and less than 0.50 , so with $95 \%$ confidence, the effect of the physical indices in the feeling of child safety is different. Indicators of urban physical effective on children's sense of safety (from the viewpoint of children) in order of great effect, are as follows:

- Are you treated well in the park?

- Is there enough light in the streets and in the park at night? 
- Are respected all children with any dress and nationality and race in your neighborhood?

- Are shops close to the park suitable?

- Are there different ways to get to the park from home?

- Do you feel safe from commuting cars around the park?

- If you are at risk out of home and in the park, is there anyone to help you?

- Do you feel secure when you are alone in the park?

- Are there in the neighborhood adult's violence and serious fights? Do you feel safe about this?

- Do you feel safe against a fight with other children?

- Do you feel safe to walk to the park?

- Are there people other than family in your neighborhood who you trust them in times of danger?

\subsection{Studying of the third question}

Third question: What is the status of an effective physical index in improving the security of parks in Mashhad region 1?

The status of an effective physical index in improving the security of parks in the area of Mashhad is determined using the nonparametric test of the sign. Given that the responses are in the 5th Likert spectrum, the average of the responses is 3, so the responses are compared with the number 3 . The results are in Table 6.

Table 6 - Signal test results to examine the status of effective physical index in improving the safety of parks in Mashhad region 1

\begin{tabular}{c|c|c|c|c|c}
\hline Factors & $\begin{array}{c}\text { Number } \\
\text { of } \\
\text { observatio } \\
\text { ns more } \\
\text { than 3 }\end{array}$ & $\begin{array}{c}\text { Number } \\
\text { of } \\
\text { observatio } \\
\text { ns less } \\
\text { than 3 }\end{array}$ & $\begin{array}{c}\text { Number } \\
\text { of } \\
\text { observatio } \\
\text { ns equal } \\
\text { to 3 }\end{array}$ & $\begin{array}{c}\text { Test } \\
\text { statisti } \\
\text { c }\end{array}$ & $\begin{array}{c}\text { Significa } \\
\text { nce level }\end{array}$ \\
\hline $\begin{array}{c}\text { Attention to the safety } \\
\text { index of playgrounds for } \\
\text { children and teens in parks }\end{array}$ & 0 & 20 & 10 & -4.472 & 0.000 \\
\hline
\end{tabular}




\begin{tabular}{l|l|l|l|l|l}
\hline $\begin{array}{l}\text { Attention to the safety } \\
\text { index of floor coverings, } \\
\text { passages and bridges for } \\
\text { children, the elderly, the } \\
\text { disabled, etc. }\end{array}$ & 0 & 30 & 0 & -5.295 & 0.000 \\
\hline $\begin{array}{l}\text { Attention to the safety } \\
\text { index of benches, electric } \\
\text { lighting gates, drinking } \\
\text { water and... for all users of } \\
\text { the park }\end{array}$ & 0 & 30 & 0 & -5.295 & 0.000 \\
\hline $\begin{array}{l}\text { Reducing out-of-visibility } \\
\text { locations and provoking a } \\
\text { sense of fear in park } \\
\text { design }\end{array}$ & 0 & 30 & 0 & -5.295 & 0.000 \\
\hline $\begin{array}{l}\text { Attention to the lighting } \\
\text { index of all parts of the } \\
\text { park at night }\end{array}$ & 0 & 30 & 0 & -5.295 & 0.000 \\
\hline
\end{tabular}

According to the above table, the level of significance for all factors is 0.000 and less than 0.05 , and the number of observations less than 3 is more than the other groups, so $95 \%$ confidence can be said:

The status of an effective index of improving the security of parks in region 1 is as follows:

- Attention to the safety index of playgrounds for children and teens in parks

- Attention to the safety index of floor coverings, passages and bridges for children, the elderly, the disabled, etc.

- Attention to the safety index of benches, electric lighting gates, drinking water, etc. for all users of the park

- Reducing out-of-visibility locations and provoking a sense of fear in park design

- Attention to the lighting index of all parts of the park at night

(Continue...) 


\subsection{Ranking the status of an effective physical index in improving the safety of parks in region 1}

In this section, with using Friedman's test, the status of an effective index of health in improving the safety of parks in region 1 , are ranked and the most important physical factors are identified.

Table 7 - Ranking of the status of an effective index in improving the security of parks in Region 1

\begin{tabular}{l|c}
\hline \multicolumn{1}{c|}{ Factors } & Average rating \\
\hline $\begin{array}{l}\text { Attention to the safety index of playgrounds for children and } \\
\text { teens in parks }\end{array}$ & 4.15 \\
\hline $\begin{array}{l}\text { Attention to the safety index of benches, electric lighting gates, } \\
\text { drinking water and... for all users of the park }\end{array}$ & 3.90 \\
\hline Attention to the lighting index of all parts of the park at night & 2.48 \\
\hline $\begin{array}{l}\text { Attention to the safety index of floor coverings, passages and } \\
\text { bridges for children, the elderly, the disabled, etc. }\end{array}$ & 2.23 \\
\hline $\begin{array}{l}\text { Reducing out-of-visibility locations and provoking a sense of fear } \\
\text { in park design }\end{array}$ & 2.23 \\
\hline Test statistic & 68.640 \\
\hline Significance level & 0.000 \\
\hline
\end{tabular}

According to the above table, the indicator "Attention to the safety index of playgrounds for children and teens in parks" is in a better position than other indicators.

\section{Conclusion}

In this study, which is done with purpose of evaluate the impact of physical indicators on child safety in Mashhad 1 area parks, the most important physical factors affecting the improvement of security of children urban parks are the attention to the lighting index of all parks at nights", and also the reduction of out-of-sight locations and inducing fear in the 
design of the parks.Also in the study of urban physical indicators in children's sense of security revealed that the behavioral welfare parameter in the park with children was the priority and in investigating the status of physical indicators effective in enhancing the security of parks in Mashhad region 1, it is specified that paying attention to children and adolescents' land safety index in parks, and to floor and passage and park bridges safety index for children, visitors, and children is a priority. Given the status of effective physical indicators in enhancing the security of parks in region 1, the children and adolescences playground safety index in the parks is in a more favorable position.

\section{Suggestions}

- Placing planned activities in the park environment, alongside an entrance or along a pedestrian pathway

- Places for supermarkets at the edge of the park, which is adjacent to the street and the park.

- Creating proper planning and design for park to use throughout the night.

- Development of activities beyond facilities and sports grounds.

- Use of comments and suggestions by users on the design or redevelopment of park spaces

- Creating clear and understandable signs to help increase the sense of security, because it allows people to guide themselves.

- The existence of official or informal monitoring of activities that are seen by other people in the parks is very important in reducing sabotage, inappropriate activities and isolation.

- Lighting to enhance perceptions of safety, although it may reduce actual body mass, but, with improved lighting and increased legitimacy, night-time monitoring increases.

- Physical access should be maximized by providing the ability to select routes that are fully legible to all areas of the park. 
- Good maintenance is essential for maintaining perceptions that are low-risk areas. Vandalism can help to understand fear, because the floor, murals, and broken furniture all indicate that a place is insecure.

Diversity can increase the amount of space usage. Variation in the shape, color and texture of the elements of the landscape, as well as a range of activities, gives the environment a spectacular look that attracts the user and removes space from the privacy.

\section{References}

Akbari Reza; Pakbonyan. Samaneh (2012), Effect of the public spaces on the sense of social security of women, Journal of Fine Arts, Volume 17, No. 2

Azmoude, Maryam (2012), Architecture and Design for Children, Science and Technology Publishing, First Edition, Tehran

Brussoni Mariana,(2012) Risky Play and Children's Safety: Balancing Priorities for Optimal Child Development,) 2012( ‘Aug 30. doi: 10.3390/ijerph9093134

Clifton L. Smith, David J. Brooks (2013), Built Environment, Chapter 4, 2013, Pages 81-103

Dannenberg Andrew, L Howard Frumkin, and Richard J. Jackson (2011). Making healthy space, designing and building for health, well-being and sustainability. Washington: Island press.

Dong Nannan (2017) Safety Research of Children's Recreational Space in Shanghai Urban Parks, Volume 198, Pages 612-621

https://www.pps.org/article/what-is-placemaking. 2018. https://www.pps.org/article/whatis- ONLINE] Available at: https://www.pps.org/article/what-is-placemaking. Accessed 13 August 2018

Kelly, Eric Damian, Crabtree, Dain (2009), Securing The Built Environment: An Analysis Crime

Kiani, Akbar; Esmaeilzadeh Kawaki, Ali (2012) Analysis and Planning in a Child Friendly City from the Perspective of Children (Case Study: Quchan), Bagh Nazar Quarterly, No. 20, pp. 51-62.

Maas Jolanda, Spreeuwenberg Peter, (2009), Is Green Space in the Living Environmen Associated with People's Feelings of Social Safety? January 1, 2009, https://doi.org/10.1068/a4196 
Meerow, S., Newell, J. P., \& Stults, M. (2016). Defining Urban Resilience: A review. Landscape and Urban Planning, 147, 38-49

Mortazavi, Sabouba (2011). Pedestrian recognition as a hub for leisure time in the city. City and Nutrition Monthly, (12), 14 - 26.

Nowroozi, Alireza; Mahin, Nastaran (2014), Children's Playground Planning (Urban Playground), Vol. 1.

Park, H (2010), Designing out Crime in South Korea: Qualitative Analysis of Contemporary CPTED-Related Issues, Asia Pacific Journal of Police \& Criminal Justice, Vol. 8 No. 2, pp. 21-48.

Qarebiglu, Minoo (2012) The Role of Environmental Factors in Nurturing Children's Creativity, Journal of Gardening, No. 19, pp. 86-91.

Rafieian, Mojtaba: Razavi, Hamadeh, (2010), Improving Urban Environmental Quality Using Design-Based Planning Approach, Journal of Space Planning and Issue 2, pp. 287. 269

Savicic Gordan, Savic Selena, (2016), Unpleasant Design , July 28, 2016

Senda, Mitsuru ,(2015), Safety in public spaces for children's play and learning, Volume 38, Issue 2, March 2015, Pages 103-115 